\title{
Route and Regulation of Zinc, Cadmium, and Iron Transport in Rice Plants (Oryza sativa L.) during Vegetative Growth and Grain Filling: Metal Transporters, Metal Speciation, Grain Cd Reduction and $\mathrm{Zn}$ and Fe Biofortification
}

\section{Tadakatsu Yoneyama $^{1, *}$, Satoru Ishikawa ${ }^{2}$ and Shu Fujimaki ${ }^{3}$}

1 Department of Applied Biological Chemistry, The University of Tokyo, Tokyo 113-8657, Japan

2 Soil Environment Division, National Institute for Agro-Environmental Sciences, Tsukuba, Ibaraki 305-8604, Japan; E-Mail: isatoru@affrc.go.jp

3 Quantum, Beam Science Center, Japan Atomic Energy Agency, Takasaki, Gunma 370-1292, Japan; E-Mail: fujimaki.shu@jaea.go.jp

* Author to whom correspondence should be addressed; E-Mail: tadakatsu_yoneyama@opal.ocn.ne.jp; Tel./Fax: +81-29-828-8303.

Academic Editor: Hatem Rouached

Received: 8 May 2015 / Accepted: 5 August 2015 / Published: 13 August 2015

\begin{abstract}
Zinc (Zn) and iron (Fe) are essential but are sometimes deficient in humans, while cadmium $(\mathrm{Cd})$ is toxic if it accumulates in the liver and kidneys at high levels. All three are contained in the grains of rice, a staple cereal. $\mathrm{Zn}$ and $\mathrm{Fe}$ concentrations in rice grains harvested under different levels of soil/hydroponic metals are known to change only within a small range, while $\mathrm{Cd}$ concentrations show greater changes. To clarify the mechanisms underlying such different metal contents, we synthesized information on the routes of metal transport and accumulation in rice plants by examining metal speciation, metal transporters, and the xylem-to-phloem transport system. At grain-filling, $\mathrm{Zn}$ and $\mathrm{Cd}$ ascending in xylem sap are transferred to the phloem by the xylem-to-phloem transport system operating at stem nodes. Grain Fe is largely derived from the leaves by remobilization. Zn and Fe concentrations in phloem-sap and grains are regulated within a small range, while $\mathrm{Cd}$ concentrations vary depending on xylem supply. Transgenic techniques to increase concentrations of the metal chelators (nicotianamine, 2'-deoxymugineic acid) are useful in increasing grain $\mathrm{Zn}$ and Fe concentrations. The elimination of OsNRAMP5 Cd-uptake transporter and the enhancement of root cell vacuolar $\mathrm{Cd}$ sequestration reduce uptake and root-to-shoot transport, respectively, resulting in a reduction of grain $\mathrm{Cd}$ accumulation.
\end{abstract}


Keywords: cadmium; iron; metals in grains; metal speciation; metal transporter; rice (Oryza sativa L.); xylem-to-phloem transport; zinc

\section{Introduction}

Zinc $(\mathrm{Zn})$ and iron (Fe) are required by plants in response to demands for plant growth, which is underlined by cellular metabolisms [1,2], while cadmium $(\mathrm{Cd})$ is not essential for plants and is toxic at high levels. Likewise, $\mathrm{Zn}$ and Fe are essential in the human metabolism and their deficiency may lead to various diseases, while $\mathrm{Cd}$ is toxic and at high doses may even cause severe diseases like Itai-Itai disease (Table 1).

Table 1. Demands and toxicity of $\mathrm{Zn}, \mathrm{Cd}$, and Fe for plants and impacts of their dietary deficiency or excess on humans.

\begin{tabular}{|c|c|c|}
\hline Metal & Demands/Toxicity for Plants & Deficiency Diseases/Excess Toxicity for Humans \\
\hline $\mathrm{Zn}$ & $\begin{array}{l}\text { Demand: Cofactor of over } 300 \text { enzymes including } \\
\text { DNA- and RNA-polymerases; } \\
\text { Excess toxicity: Unregulated binding of Zn to S-, } \\
\text { N- and O-containing molecules }\end{array}$ & $\begin{array}{c}\text { Deficiency: Stunting, diarrhea, pneumonia; } \\
\text { Excess toxicity: Interference of } \mathrm{Fe} \text { and } \mathrm{Cu} \text { uptake } \\
\text { in the intestines }\end{array}$ \\
\hline $\mathrm{Cd}$ & $\begin{array}{l}\text { Toxicity: Binding to protein } \mathrm{SH}-\text { residues, exchanges } \\
\text { with divalent cations such as } \mathrm{Zn}^{2+} \text { and } \mathrm{Ca}^{2+} \text {, and } \\
\text { excessive production of reactive oxygen species }\end{array}$ & $\begin{array}{l}\text { Excess toxicity: Itai-itai disease (spinal and leg bone } \\
\text { pain) caused by Cd accumulation in the liver and } \\
\text { kidneys resulting in tubular renal dysfunction, } \\
\text { osteoporosis, cancer, and cardiovascular diseases }\end{array}$ \\
\hline $\mathrm{Fe}$ & $\begin{array}{l}\text { Demand: Proteins involved in redox and electron } \\
\text { transport. Leaf pigment formation; } \\
\text { Toxicity: Free Fe can generate toxic levels of } \\
\text { oxygen and hydroxyl free radicals through the } \\
\text { Fenton reaction }\end{array}$ & $\begin{array}{l}\text { Deficiency: Anemia, impaired mental development; } \\
\text { Iron overload: Excessive accumulation of Fe } \\
\text { in the liver, heart, and pancreas. } \\
\text { Hemosiderosis; Hemochromatosis }\end{array}$ \\
\hline
\end{tabular}

Literature sources: Palmgren et al. [3], White and Broadley [4], and Clemens et al. [5].

Zinc and $\mathrm{Fe}$ in the grains of cereals such as rice are essential elements for humans. However, humans' intake of $\mathrm{Zn}$ and $\mathrm{Fe}$ is generally not sufficient [3,6,7]. In contrast, $\mathrm{Cd}$, which is sometimes contained at high levels in the rice grains grown in Cd-contaminated soils, is toxic for humans [8]. Therefore, it is necessary to enrich rice grains with $\mathrm{Zn}$ and Fe and to decrease their Cd content [9].

Fukushima et al. [8] reported that, in the district where "Itai-Itai disease" was endemic, soil Cd levels ranged from 0.4 to $8 \mathrm{mg} \cdot \mathrm{kg}^{-1}$ (dry soil) and those of brown rice were correlated, varying between 0.2 to $2 \mathrm{mg} \cdot \mathrm{kg}^{-1}$ (dry weight), while in the case of $\mathrm{Zn}$ levels, although soil $\mathrm{Zn}$ levels varied greatly from 50 to $1200 \mathrm{mg} \cdot \mathrm{kg}^{-1}$, those of brown rice had a much smaller range from 20 to $30 \mathrm{mg} \cdot \mathrm{kg}^{-1}$. (Names of rice plant parts are shown in Figure 1). 

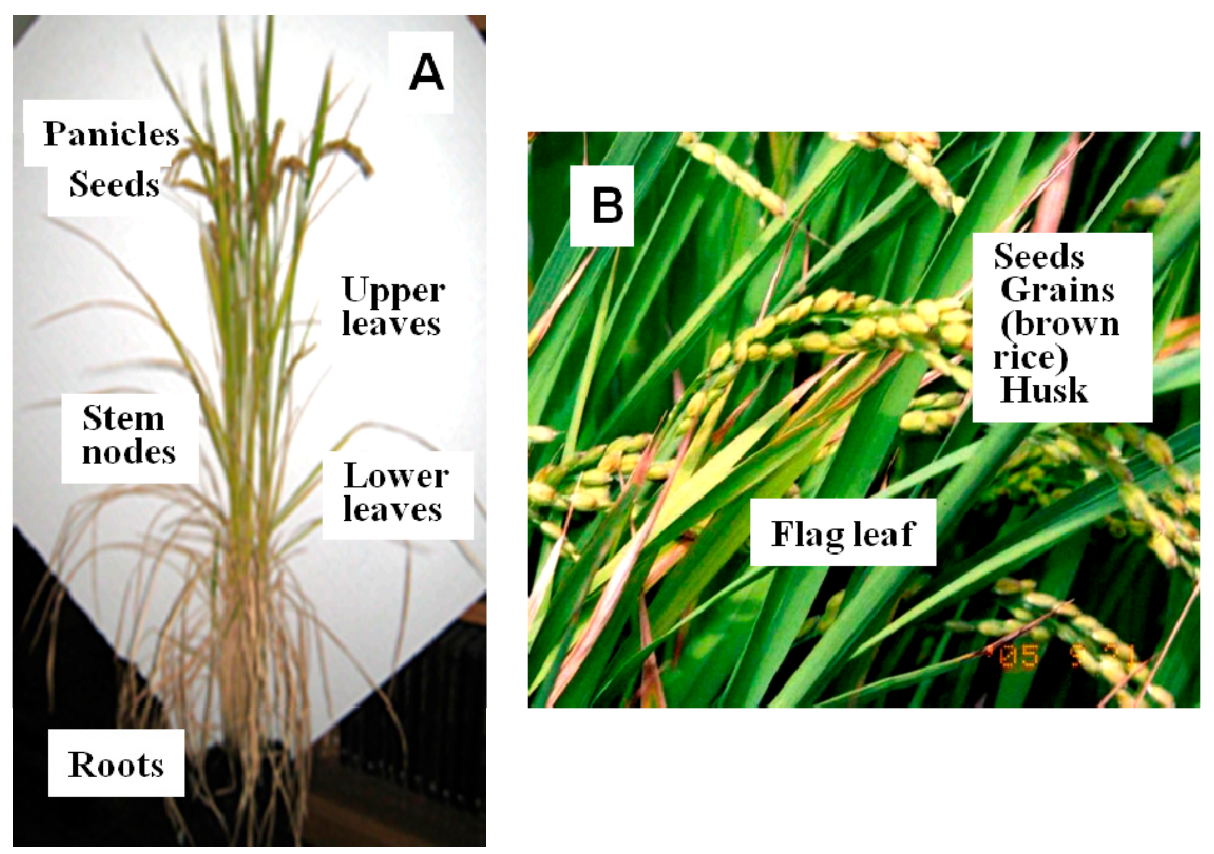

Figure 1. Rice plants (cv. Koshihikari) grown in potted soil (A) and in a field (B) at maturity.

Recent field studies in Thailand by Simmons et al. [10] on Cd, Zn, and Fe accumulation in rice grains (unpolished rice) under $\mathrm{Cd} / \mathrm{Zn}$ contaminated soils, containing $2.9-284 \mathrm{mg} \cdot \mathrm{kg}^{-1} \mathrm{Cd}, 254-8036 \mathrm{mg} \cdot \mathrm{kg}^{-1} \mathrm{Zn}$, and $0.5-25 \mathrm{mg} \cdot \mathrm{kg}^{-1} \mathrm{Fe}$, indicated that the harvested grains contained variable concentrations of $\mathrm{Cd}$ ranging from 0.02 to $5.0 \mathrm{mg} \cdot \mathrm{kg}^{-1}$, but relatively constant concentrations of $\mathrm{Zn}$ (from 15 to $25 \mathrm{mg} \cdot \mathrm{kg}^{-1}$ ) and $\mathrm{Fe}$ (from 7.5 to $12.7 \mathrm{mg} \cdot \mathrm{kg}^{-1}$ ), although the concentrations of all three metals varied greatly in the stems and leaves. Thus, $\mathrm{Zn}$ and Fe levels in rice grains are little affected by the availability of $\mathrm{Zn}$ and $\mathrm{Fe}$ in the soil, while grain Cd levels vary greatly. Grain $\mathrm{Zn}$ concentrations in rice plants grown in the Philippines were unchanged by $\mathrm{Zn}$ fertilization $\left(15 \mathrm{~kg} \mathrm{Zn} \cdot \mathrm{ha}^{-1}\right)$, while this $\mathrm{Zn}$ fertilization increased straw $\mathrm{Zn}$ concentrations by $43 \%-95 \%$ [11].

When a rice cultivar (Todorokiwase) was grown in a culture solution at 0.01 to $3.0 \mathrm{mg} \cdot \mathrm{L}^{-1} \mathrm{Cd}$, the $\mathrm{Cd}$ concentrations in the leaf blades greatly increased from 3 to $100 \mathrm{mg} \cdot \mathrm{kg}^{-1}$ and those in the grains also increased from 0.5 to $10 \mathrm{mg} \cdot \mathrm{kg}^{-1}$ [12]. In contrast, when $\mathrm{Zn}$ concentrations in the culture solution were increased from 0.05 to $20 \mathrm{mg} \cdot \mathrm{L}^{-1}$, $\mathrm{Zn}$ concentrations in the leaf blades greatly increased from 50 to $2500 \mathrm{mg} \cdot \mathrm{kg}^{-1}$, but those in the grains increased only slightly from 33 to $80 \mathrm{mg} \cdot \mathrm{kg}^{-1}$ [13]. Recently, Jiang et al. [14] reported that when a rice cultivar (Handao297) grown in a nutrient solution containing $\mathrm{Zn}$ at 0.15 to $2250 \mu \mathrm{M}, \mathrm{Zn}$ concentrations in the shoots greatly changed from 53 to $1540 \mathrm{mg} \cdot \mathrm{kg}^{-1}$, while those in brown rice changed only slightly from 52 to $106 \mathrm{mg} \cdot \mathrm{kg}^{-1}$.

These results suggest that specific regulatory mechanisms for each of the three metals may exist between the xylem delivery to stems and leaves and the allocation of the metals to grains. In this review, to determine the regulation of the transport on $\mathrm{Zn}, \mathrm{Cd}$, and $\mathrm{Fe}$ via the xylem and phloem, we synthesized information of $\mathrm{Zn}, \mathrm{Cd}$, and $\mathrm{Fe}$ concentrations and their chemical forms in xylem and phloem saps, the localizations of metal transporters, and finally the routes of transport of these metals to the grains. 


\section{Uptake at Root-Surface Membranes and Radial Transport to the Xylem}

Plant availability of metals from soils is controlled by three steps: (1) soil conditions (upland or flooded soil, soil solution $\mathrm{pH}$ ); (2) mineralization (ionization and complex formation); and (3) uptake transporters.

As shown in Figure 2, $\mathrm{Zn}$ in both drained and flooded soils is largely ions $\left(\mathrm{Zn}^{2+}\right)$, although some $\mathrm{Zn}$ may be bound to organic substances, and immobilized as $\mathrm{Zn}$-sulfide ( $\mathrm{ZnS})$ in the anaerobic layer [15]. Cadmium in drained acidic soils is ionized as $\mathrm{Cd}^{2+}$, while $\mathrm{Cd}$ in paddy alkaline soils is present in the forms of $\mathrm{CdCO}_{3}$ and humic acid-bound $\mathrm{Cd}[16] . \mathrm{Cd}$ is immobilized as $\mathrm{Cd}$-sulfide (CdS) and colloids-bound $\mathrm{Cd}$ by flooding of soils [17]. Drainage converts $\mathrm{CdS}$ to $\mathrm{Cd}^{2+}$ and dramatically increases its availability to plants. $\mathrm{Fe}$ in acidic soils is ionized as $\mathrm{Fe}^{2+} / \mathrm{Fe}^{3+}$, while in aerobic alkaline soils $\mathrm{Fe}$ is immobilized as $\mathrm{Fe}(\mathrm{OH})_{3}$.
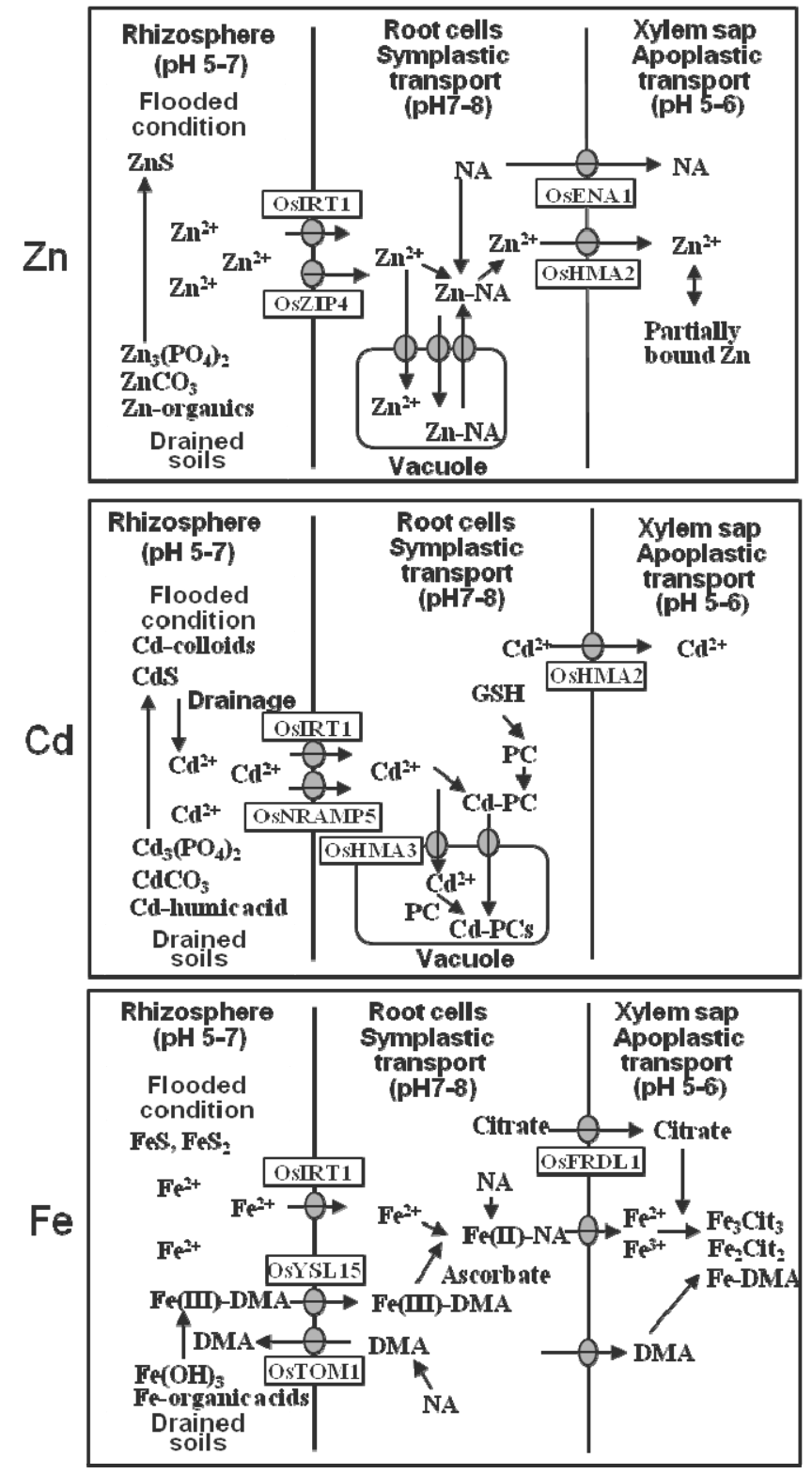

Figure 2. Models of uptake and transport of $\mathrm{Zn}, \mathrm{Cd}$, and $\mathrm{Fe}$ in rice roots. DMA, 2'-deoxymugineic acid; GSH, glutathione; NA, nicotianamine; PC, phytochelatin. Arrows indicate flows of substances and grey ellipses indicates transporters. 
Table 2. Transporters involved in the acquisition and inter-organ transport of $\mathrm{Zn}, \mathrm{Cd}$, and $\mathrm{Fe}$ in rice plants.

\begin{tabular}{|c|c|c|c|}
\hline Site & $\mathbf{Z n}$ & Cd & $\mathbf{F e}$ \\
\hline Acquisition at root cell membranes & OsIRT1 ${ }^{1}$; OsZIP4, $5^{2}$ & $\begin{array}{l}\text { OsNRAMP5 }^{3} ; \\
\text { OsIRT1/OsIRT2 }\end{array}$ & OsYSL1 $5^{5}$; OsIRT1/OsIRT2 ${ }^{6}$ \\
\hline $\begin{array}{l}\text { Vacuolar import through the tonoplast } \\
\text { in root cells }\end{array}$ & $(\mathrm{ZIF} 1)^{7}$ & OsHMA $^{8}$ & \\
\hline Xylem loading at root pericycle cells & OsHMA2 ${ }^{9}$ & OsHMA2 5,9 & \\
\hline Xylem-to-phloem transport at nodes & OsHMA2 ${ }^{10}$ & OsHMA2 ${ }^{10}$ & OsYSL16 ${ }^{11}$ \\
\hline Phloem loading after mobilization in leaves & ZIP and YSL families & & OYSL15 ${ }^{12}$ \\
\hline Phloem unloading at reproductive organs & & & OsYSL18 ${ }^{13}$ \\
\hline
\end{tabular}

${ }^{1}$ Lee and An [18]; ${ }^{2}$ White and Broadley [4]; ${ }^{3}$ Ishikawa et al. [19], Sasaki et al. [20]; ${ }^{4}$ Nakanishi et al. [21];

${ }^{5}$ Inoue et al. [22]; ${ }^{6}$ Ishimaru et al. [23]; ${ }^{7}$ Haydon et al. [24]; ${ }^{8}$ Ueno et al. [25]; ${ }^{9}$ Nocito et al. [26], Takahashi et al. [27]; ${ }^{10}$ Yamaji et al. [28]; ${ }^{11}$ Kakei et al. [29]; ${ }^{12}$ Lee et al. [30]; ${ }^{13}$ Aoyama et al. [31].

As shown in Table 2, the uptake of these metals at root-surface membranes is driven by specific uptake transporters, $\mathrm{Zn}^{2+}, \mathrm{Cd}^{2+}$, and $\mathrm{Fe}^{2+}$ commonly by OsIRT1 (rice iron-regulated transporter1) $[18,21,23]$ and $\mathrm{Cd}^{2+}$ predominantly by OsNRAMP5 (rice natural resistance-associated macrophage protein5) [19]. The possible uptake of some $\mathrm{Zn}$-phytosiderophores together with the uptake of $\mathrm{Zn}^{2+}$ by a $\mathrm{Zn}$-deficiency-tolerant line of rice has been suggested under lowland conditions [32]. Iron $\left(\mathrm{Fe}^{3+}\right)$ in neutral and alkaline soils binds to mineral crystals and organic substances so strongly that such soil ions are barely available to plants and the iron is solubilized by forming a complex with a phytosiderophore, 2'-deoxymugineic acid (DMA) [33], which is excreted by rice roots by OsTOM1 (rice DMA effluxer) [34]. Fe(III)-DMA complexes in the soil solution are taken up by OsYSL15 (rice yellow stripe-like15) [22]. Under flooded conditions, rice plants may absorb both Fe(III)-DMA and $\mathrm{Fe}^{2+}[23]$.

Zinc $\left(\mathrm{Zn}^{2+}\right)$ and $\mathrm{Fe}^{2+}$ in root cell cytosols form complexes with nicotianamine (NA) in the forms of Zn-NA and Fe(II)-NA (Figure 2). Cadmium in the root cell cytosols may be $\mathrm{Cd}^{2+}$ ions or complexes with phytochelatins (PCs). Fe(III)-DMA absorbed in the root cell cytosols can be reduced by ascorbate, transforming to Fe(II)-NA [35]. Fe of cytosolic Fe(II)-NA may be excreted to the xylem and makes complexes predominantly with citrate ( $\left.\mathrm{Fe}_{2} \mathrm{Cit}_{2}, \mathrm{Fe}_{3} \mathrm{Cit}_{3}\right)$ and some with DMA (Fe-DMA) [36].

Root cell vacuoles can function as a storage compartment for metals. Zn-NA in the root cell cytosols is transferred to the vacuoles by the ZIF1 (zinc induced facilitor1) transporter [24]. Cadmium in the cell cytosols may be partly sequestered through the tonoplast as $\mathrm{Cd}^{2+}$ by OsHMA3 (rice heavy metal ATPase3) [25] and as Cd-PC complex, presumably by ABCC-type transporters in Arabidopsis [37], and both are stored as Cd-PCs in the vacuoles. Enhancement of OsHMA3 activity has been found to increase storage in roots and decrease the transport of $\mathrm{Cd}$ to the shoot and the final accumulation of $\mathrm{Cd}$ in rice grains [25]. A high rate of root-to-shoot transport and subsequent accumulation in the grains of ${ }^{107} \mathrm{Cd}$, which was administered from a culture solution, was observed in OsHMA3-depleted rice lines [38].

OsHMA2, which localizes at the root pericycle, is a major transporter of $\mathrm{Zn}$ and $\mathrm{Cd}$ for xylem loading [26,27]. The excretion of citrate from the root cells to the xylem is partly operated by OsFRDL1 (rice ferric reductase defective1-like) to enhance Fe-transport in the xylem as Fe(III)-citrate complex [39]. 


\section{Xylem and Phloem Transport}

The concentrations of $\mathrm{Zn}, \mathrm{Cd}$, and $\mathrm{Fe}$ and their chemical forms in rice xylem and phloem saps from 28- to 33-day-old vegetative plants were analyzed. The phloem sap was collected by a unique and excellent technique using the insect-laser method as described by Kawabe et al. [40]. Briefly, the insects used were Nilaparvata lugens Stål (brown planthopper). Rice plants at the 8th to 9th leaf-age were transferred to $500 \mathrm{~mL}$ plastic bottles, one plant per bottle, and placed in an artificially lit chamber $\left(130 \mu \mathrm{mol} \cdot \mathrm{m}^{-2} \cdot \mathrm{s}^{-1}\right.$ photosynthetically active irradiation, $12 \mathrm{~h}$ light and $12 \mathrm{~h}$ dark cycle). After the plants' adaptation to the environment over 1 or 2 days, overhead projector film sheet cylinders $(3 \mathrm{~cm}$ high, $1 \mathrm{~cm}$ in diameter) with cotton stoppers on both sides were set on the sheaths of the fully developed leaves, and female insects, that had been forced to fast overnight, were transferred into the cylinders to allow the insects to suck the phloem sap. After 1-3 h, the insects' stylets were cut by a YAG laser (SL129Nd; NEC, Tokyo, Japan) beam. After the phloem sap was collected, shoots were cut with a knife at $2 \mathrm{~cm}$ from the root-shoot interface and the exudates (xylem sap) from the cut surfaces were collected.

The $\mathrm{Zn}$ concentrations in the xylem and phloem saps under four different $\mathrm{Zn}$ concentrations in the culture solution are shown in Figure 3. The Zn concentrations in the xylem sap increased with those in the culture solution, while the $\mathrm{Zn}$ concentrations in the phloem sap varied only slightly between 55 and $100 \mu \mathrm{M}$. With $0.1 \mu \mathrm{M}$ culture-solution $\mathrm{Cd}$, the xylem and phloem $\mathrm{Cd}$ concentrations were around 20 -fold higher than the culture-solution Cd concentrations. Under treatment with $10 \mu \mathrm{M} C d$, xylem sap was not exuded due to wilting. Cd concentrations in the collected phloem sap increased with the medium Cd concentrations (Figure 3). Although the Fe concentrations in the culture solution ranged greatly at 4.5, 9.0, 45 and $90 \mu \mathrm{M}$, xylem Fe concentrations remained nearly constant at $12 \mu \mathrm{M}$ under the lower three culture-solution Fe treatments and $16 \mu \mathrm{M}$ under the $90 \mu \mathrm{M}$ treatment (Figure 3). Phloem-sap Fe concentrations, around $50 \mu \mathrm{M} \mathrm{Fe}$, were not affected by the different Fe treatments.

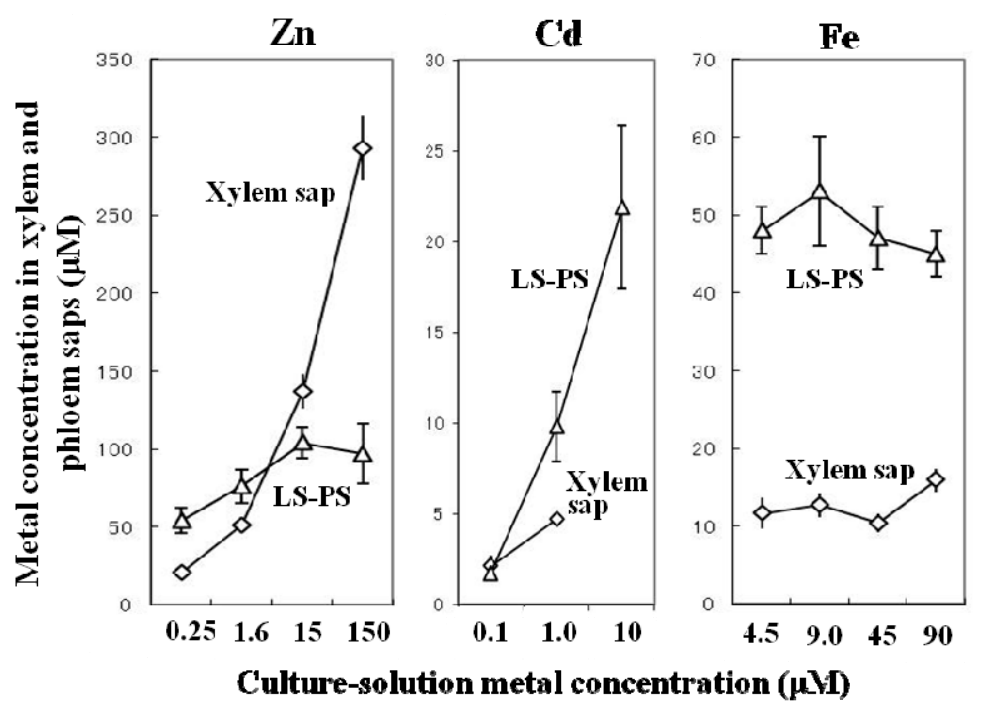

Figure 3. Metal concentrations in the xylem and phloem saps of vegetative rice plants under various culture-solution metal concentrations. Phloem sap was collected from the leaf sheaths (LS-PS) of the 7th leaves. Data for Zn and Fe are from Nishiyama [41], and data for $\mathrm{Cd}$ are from Mariyo Kato [42]. 
The chemical forms in xylem and phloem saps from young rice plants are shown in Table 3. Using the phloem and xylem saps collected as described above, chemical forms (speciation) of $\mathrm{Zn}, \mathrm{Cd}$, and $\mathrm{Fe}$ in such saps were investigated using size-exclusion high performance liquid chromatography (SE-HPLC, Hitachi, Tokyo, Japan), inductively coupled plasma-mass spectrometry (ICP-MS, Yokogawa, Tokyo, Japan), capillary electrophoresis coupled to mass spectrometry (CE-MS, Agilent Technologies, Walbronn, Germany), and electrospray ionization time-of-flight mass spectrometry (ESI-TOF MS, JOC, Tokyo, Japan).

The $\mathrm{Zn}$ chemical forms in xylem sap are free ions and $\mathrm{Zn}$ partially bound to unidentified chelators [39], while the $\mathrm{Zn}$ in phloem sap was dominantly bound to NA [43]. The Cd chemical form in the xylem sap is primarily in free ions (Mariyo Kato [42]), while the $\mathrm{Cd}$ in the phloem sap was largely bound to specific proteins although some $\mathrm{Cd}$ was bound to low-molecular thiol compounds [44]. The Fe chemical forms in xylem sap were found to be bound largely to citrate (around 65\%) and slightly to DMA (around 5\%) [36], while the Fe in phloem sap bound to DMA, citric acid, and proteins [43]. Recently, metal species in the xylem and phloem saps from various plants including rice were summarized by Álvarez-Fernández et al. [45].

Table 3. Chemical forms of $\mathrm{Zn}, \mathrm{Cd}$. Fe, and $\mathrm{Cu}$ in xylem and phloem saps from rice plants. Metal speciation analyses in xylem and phloem saps were conducted by using SE-HPLC, ICP-MS, CE-MS, and ESI-TOF MS.

\begin{tabular}{|c|c|c|}
\hline Metal & Chemical Forms in Xylem Sap (pH 6) & Chemical Forms in Phloem Sap (pH 8) \\
\hline $\mathrm{Zn}$ & Free ions and partially bound ${ }^{1}$ & Bound dominantly to NA ${ }^{2}$ \\
\hline $\mathrm{Cd}$ & Primarily in free ions ${ }^{3}$ & $\begin{array}{c}\text { Bound largely to specific proteins and slightly } \\
\text { to thiol-compounds } 4\end{array}$ \\
\hline $\mathrm{Fe}$ & $\begin{array}{l}\text { Bound largely to citrate (around } 65 \% \text { ) and slightly to DMA } \\
\text { (around 5\%) and some in free ions }{ }^{5}\end{array}$ & Bound to DMA, citrate, and proteins ${ }^{2}$ \\
\hline $\mathrm{Cu}$ & Bound dominantly to $\mathrm{DMA}^{6}$ & Bound to NA, histidine and proteins ${ }^{6}$ \\
\hline
\end{tabular}

Changes in copper $(\mathrm{Cu})$ concentrations in xylem and phloem saps and the chemical forms of $\mathrm{Cu}$ in rice xylem and phloem saps were investigated by Ando et al. [46]. Xylem Cu concentrations were found to range slightly between 5 and $8 \mu \mathrm{M}$ when culture-solution $\mathrm{Cu}$ concentrations ranged from 0.16 to $1.28 \mu \mathrm{M}$ and the $\mathrm{Cu}$ in xylem sap was dominantly bound to DMA. Phloem sap $\mathrm{Cu}$ concentrations ranged between 21 and $43 \mu \mathrm{M}$ and the $\mathrm{Cu}$ in phloem sap was bound to NA, histidine and proteins.

Based on the results on variation in metal concentrations (Figure 3 ) and their chemical forms in xylem and phloem saps (Table 3), the following interesting relationship regarding the regulatory mechanisms that underlie the different changes in the $\mathrm{Zn}, \mathrm{Cd}, \mathrm{Fe}$, and $\mathrm{Cu}$ concentrations in both saps is suggested; if xylem sap contains substantial free metal ions as in the cases of $\mathrm{Zn}$ and $\mathrm{Cd}$, its metal concentration increases with increasing culture-solution metal concentration, while if xylem sap contains metal-ligand complexes as in the cases of $\mathrm{Fe}$ and $\mathrm{Cu}$, its metal concentration remains nearly constant. If the metals in the phloem saps are definitely bound to ligands as in the cases of $\mathrm{Zn}-\mathrm{NA}, \mathrm{Fe}-\mathrm{DMA}$, and $\mathrm{Cu}-\mathrm{NA}$, the metal concentration remains quite constant. The concentration of NA, which may bind $\mathrm{Zn}$ and $\mathrm{Cu}$ in rice phloem sap, was around $70 \mu \mathrm{M}[43,45]$, and that of DMA, which may bind Fe in rice phloem sap, was 
around $150 \mu \mathrm{M}$ [43]. However, phloem $\mathrm{Cd}$ is apparently an exception; phloem concentrations changed with culture-solution and xylem-sap Cd concentrations (Figure 3). The major form of $\mathrm{Cd}$ in the phloem saps is protein-bound and the Cd-binding capacity of the proteins may be sufficient to load all $\mathrm{Cd}$ in the phloem sap [44].

With respect to the transport of $\mathrm{Zn}$ in xylem sap to rapidly growing leaves, Obata and Kitagishi [47] indicate that some $\mathrm{Zn}$ ascending via the xylem (transpiration stream) is transferred to the phloem at the vegetative nodes in addition to the $\mathrm{Zn}$ which is mobilized from mature leaves (Figure 4). Together this $\mathrm{Zn}$ with different origins is terminated to the intercalary meristem to synthesize ribosomes [48]. Such active transport through both routes supports the high $\mathrm{Zn}$ accumulation at the meristem, which has been reported to reach $300 \mathrm{mg} \mathrm{Zn} \cdot \mathrm{kg}^{-1}$ dry weight (DW) in the rapidly growing leaf part as compared to $30 \mathrm{mg} \mathrm{Zn} \cdot \mathrm{kg}^{-1} \mathrm{DW}$ in the mature leaves [49]. Figure 5 shows this unique and quick accumulation of $\mathrm{Zn}$ in the early stage of leaves compared to the slow accumulation of $\mathrm{Fe}$ and also the early initiation of the decrease after the peak of $\mathrm{Zn}$ content, which was one week before reaching the DW peak [49]. The amount of $\mathrm{Zn}$ transferred to the phloem via the xylem-to-phloem transfer system seems to be regulated and constant: the transfer rate of $\mathrm{Zn}$ from xylem sap is relatively high when the xylem sap $\mathrm{Zn}$ concentration is low, and low when the xylem sap $\mathrm{Zn}$ concentration is high [50]. The ratio of the $\mathrm{Zn}$ deprived by the xylem-to-phloem transfer to that remobilized from the leaves is estimated to be around 3:7 [49]. Partitioning of $\mathrm{Cd}$ to the top may be similar to that of $\mathrm{Zn}$ and the vegetative nodes may also be the site of the xylem-to-phloem transfer of $\mathrm{Cd}[51] .{ }^{115 \mathrm{~m}} \mathrm{Cd}$ absorbed by roots is partitioned to the dwarf stem and leaves by the pattern of accumulation in the nodal part of the stem, and transport is then predominant to the rapidly growing leaves with little to the mature leaves [52], similar to that of ${ }^{65} \mathrm{Zn}$ [50]. Recently, preferential movement of ${ }^{109} \mathrm{Cd}$ and ${ }^{45} \mathrm{Ca}$, which were administered to a root-bathing solution as ${ }^{109} \mathrm{CdCl}_{2}$ and ${ }^{45} \mathrm{CaCl}_{2}$, to the newest leaf by transfer to the phloem at the stem, was confirmed by radioisotope imaging [53]. The rate of Fe involved in xylem-to-phloem transfer could be smaller than that of $\mathrm{Zn}$, since the demand-time of Fe is late compared to that of $\mathrm{Zn}$ (Figure 5, [49]). It is interesting to note that $\mathrm{Fe}$ in rice xylem sap has been found to contain small amounts of Fe-DMA and large amounts of Fe-citrate while the Fe in the xylem sap of barley plants includes a considerable fraction of Fe-mugineic acid (MA) [36]. Barley plants can transfer such xylem sap Fe-MA to the young leaves through the xylem-to-phloem system at nodes as revealed by ${ }^{52} \mathrm{Fe}$ tracing [54]. 


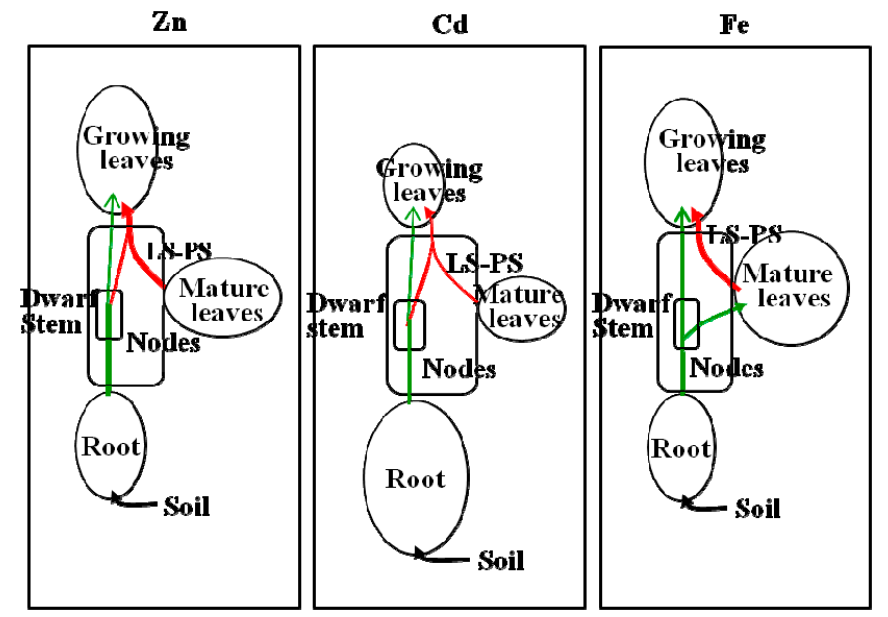

Figure 4. Models of the transport of $\mathrm{Zn}, \mathrm{Cd}$, and Fe via xylem and phloem in rice plants at the vegetative stage. "Leaves" are leaf blades. "Stem" includes the dwarf culm and leaf sheaths. The green line shows xylem transport. The red line shows phloem transport. Phloem sap was collected from the leaf sheaths (LS-PS). Information is from Yoneyama et al. [55]. Important note: At the vegetative nodes of the dwarf stem, $\mathrm{Zn}$ and $\mathrm{Cd}$ ascending xylem (green line) are transferred to the phloem (red line) via the xylem-to-phloem transfer system at the nodes, while Fe in the xylem (in the form of Fe-citrate) does not pass through this system.

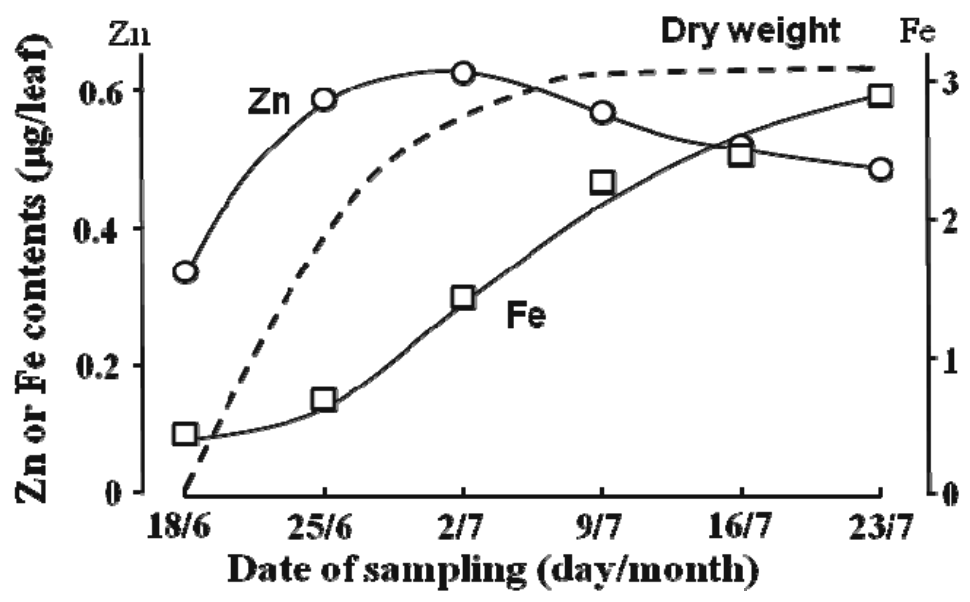

Figure 5. Changes in $\mathrm{Zn}$ and $\mathrm{Fe}$ amounts in the blade of the 10th leaf along with dry weight growth. (Adapted from Obata and Kitagishi [49]). The dry weight of the leaf was drawn arbitrarily as the dry weight at 23/7 had reached the maximum. $\bigcirc$ : change in the content of $\mathrm{Zn}$; $\square$ : change in the content of Fe. (Adapted from Obata and Kitagishi [49]).

Xylem transfer cells found in vegetative nodes [56-58] and localized metal transporters (Table 2) may support the active xylem-to-phloem transfer of xylem sap $\mathrm{Zn}$ and $\mathrm{Cd}$.

\section{Accumulation of $\mathrm{Zn}, \mathrm{Cd}$, and Fe in Rice Grains}

Phloem and xylem saps were collected from rice plants grown in Cd-contaminated flooded soil. Phloem sap was obtained from leaf sheaths at the 10th and 14th leaf ages and from the uppermost 
internodes at the grain-filling stage (Figure 6 [55]). Phloem loading after both remobilization from the leaves and stems and xylem-to-phloem transfer at stem and panicle nodes of the currently ascending fluids may be the source of grain $\mathrm{Zn}[55,59,60]$ and $\mathrm{Cd}[55,61,62]$, but for Fe the route of remobilization from other organs may be dominant as shown in Figure 7. The contribution of the xylem-to-phloem transfer rate of $\mathrm{Zn}$ and probably also of $\mathrm{Cd}$ is evident from the high and increased $\mathrm{Zn}$ concentration in phloem sap collected at the uppermost internode as compared to that collected from leaf sheaths at the 14th-leaf stage; in contrast, no such increase was observed for Fe (Figure 6). A positron-emitting ${ }^{107} \mathrm{Cd}$ imaging study of hydroponically grown rice plants at the panicle-initiation stage suggests the highly preferential transport of currently absorbed $\mathrm{Cd}$ to the panicles through the presumed xylem-to-phloem transfer at the nodes (Figure 8) [63]. The presence of xylem transfer cells in the nodes [56] and in the spikelet nodes at the region of the rachilla and pedicle $[64,65]$ and metal transporters, OsHMA2 for $\mathrm{Zn}$ and Cd [28] and OsYSL16 (rice yellow stripe-like16) for Fe-DMA [29] although the fraction of Fe-DNA is small [36], may be involved in the active xylem-to-phloem transfer of minerals (at the nodes) currently ascending via the xylem from the roots. The amount of transfer of $\mathrm{Zn}$ via the xylem-to-phloem system may be highly regulated at a certain level where there is a large supply of $\mathrm{Zn}$ through the xylem, as shown in wheat detached panicles [66]. In contrast, such a restriction may not work in the transport of $\mathrm{Cd}$, since the $\mathrm{Cd}$ concentration ascending the xylem is much smaller than that of Zn. Jiang et al. [67] demonstrated the efficient transport to the grains and little partitioning to the leaves of ${ }^{65} \mathrm{Zn}$ applied to rice plants from a culture solution during the flowering period. Rodda et al. [62] estimated that $60 \%$ of the final grain Cd could be attributed to remobilization from other tissues and the rest (40\%) from uptake during grain maturation. Importantly, mineral transporters for xylem-to-phloem transport at the nodes (OsHMA2, OsYSL16), for the phloem loading at leaves (OsYSL15), and for unloading at panicles (OsYSL18) may play important functions in the regulation of metal transport (Table 2).

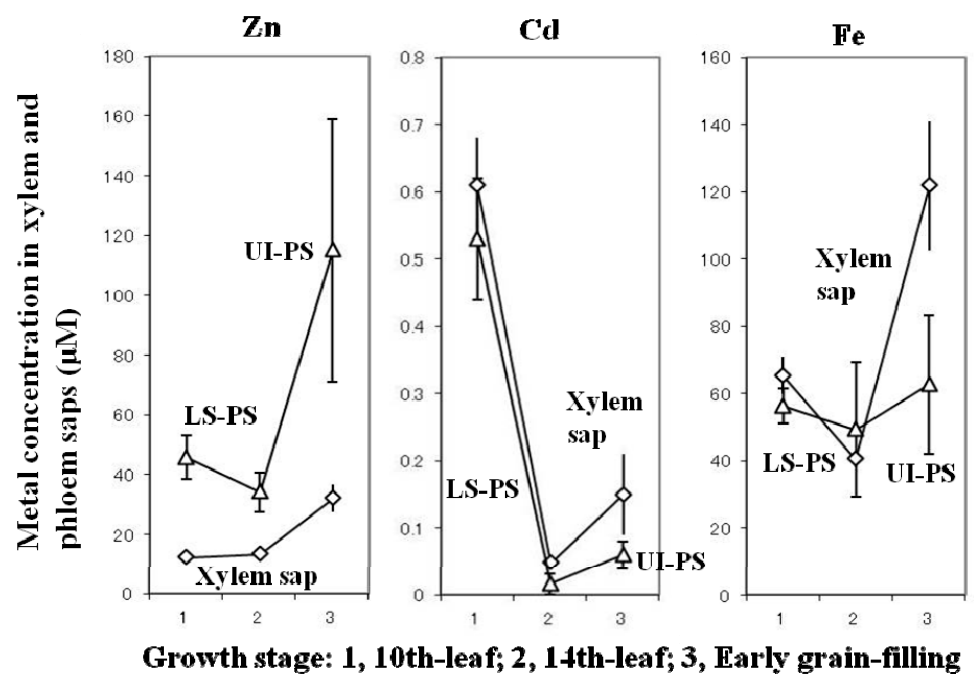

Figure 6. Metal concentrations in the xylem and phloem saps obtained from rice plants grown in a flooded Cd-contaminated soil. Phloem sap was collected from the leaf sheaths (LS-PS) of the 9th leaves at 10th-leaf stage and the 13th leaves at 14th-leaf stage, and from the uppermost internodes (UI-PS) at early grain-filling. Data are from Yoneyama et al. [55]. $\diamond$ : metal concentrations in the xylem sap, $\Delta$ : metal concentrations in the phloem sap. 


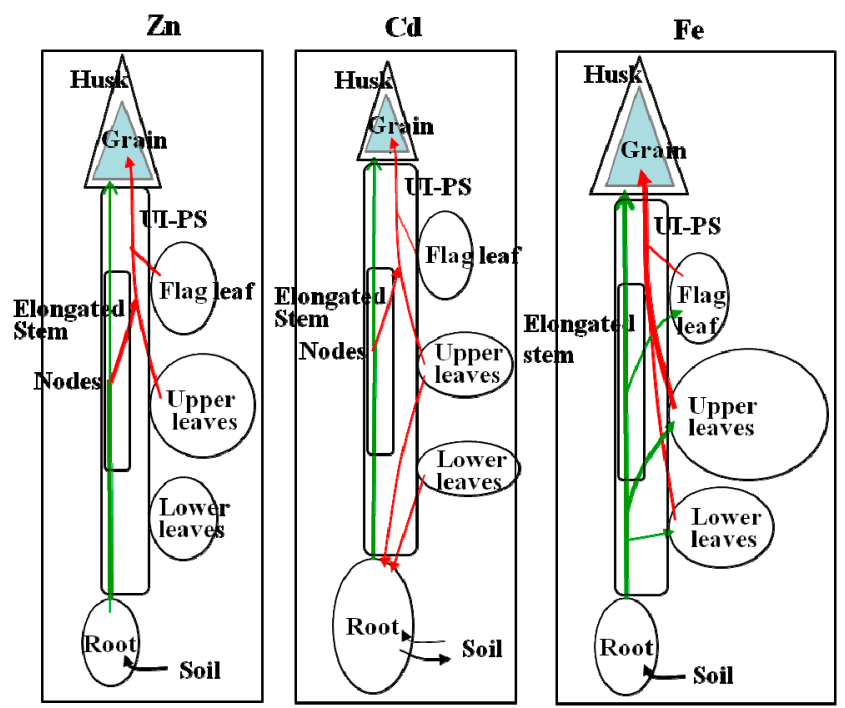

Figure 7. Models of the transport of $\mathrm{Zn}, \mathrm{Cd}$, and Fe via xylem and phloem in rice plants at grain filling. "Leaves" are Leaf blades. "Stem" includes elongated culm, leaf sheaths, and panicles except husk and grain. Green line shows xylem transport. Red line shows phloem transport. Phloem sap was collected from the uppermost internode (UI-PS). Information is from Yoneyama et al. [55]. Important note: At the nodes in the elongated stem, $\mathrm{Zn}$ and $\mathrm{Cd}$ ascending xylem (green line) are transferred to phloem (red line) via the xylem-to-phloem transfer system, while Fe in the xylem (in the form of Fe-citrate) does not pass through this system.

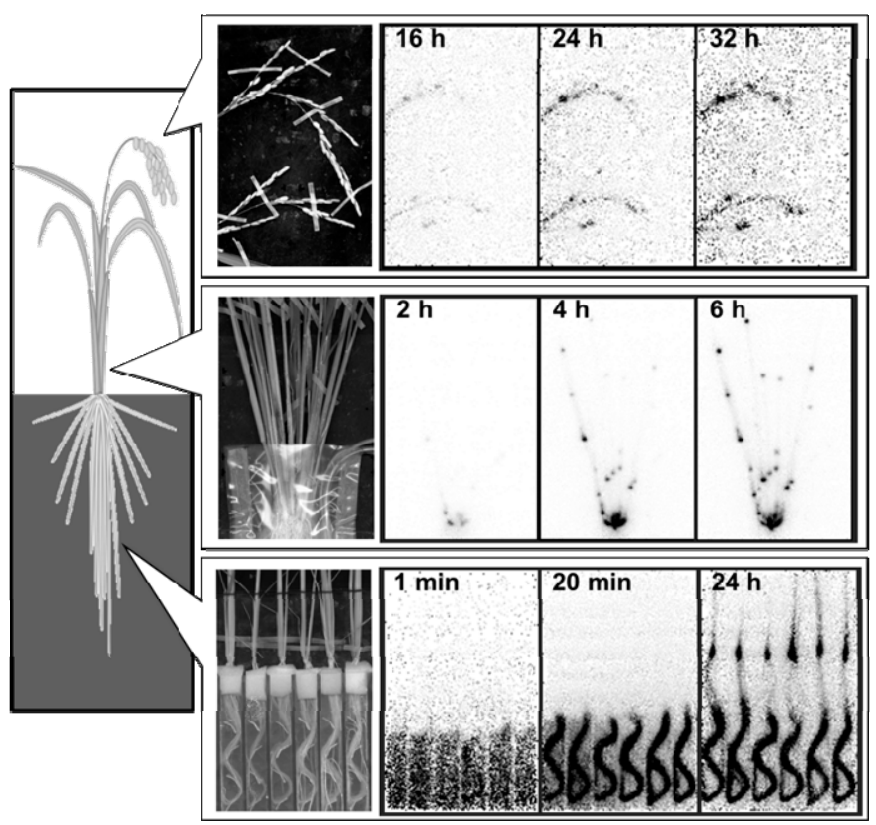

Figure 8. Movement of ${ }^{107} \mathrm{Cd}$ in rice plants administered from the root-bathing solution visualized with a positron-emitting tracer imaging system (PETIS). Regenerated from the original data of Ishikawa et al. [38] and Fujimaki et al. [62]. Important note: The images show the uptake and accumulation of ${ }^{107} \mathrm{Cd}$ by roots, transport to the shoots accompanying accumulation at the nodes (probably occurring during xylem-to-phloem transport), and final destination in the grains. 
The deposition of metals in grains is revealed as metal partitioning: $\mathrm{Zn}$ and Fe, which combine with phytic acid, are largely accumulated in the aleurone cell layer $[4,68]$ but their concentrations are reduced in white rice by polishing, while a large proportion of $\mathrm{Cd}$ is localized at the storage protein (glutelin) in the endosperm [69] and the Cd concentration in white rice is unchanged by polishing.

As stated in the Introduction section above, the $\mathrm{Zn}$ concentration in rice grains is affected only slightly by the availability of culture-solution metals, as compared to the great changes in $\mathrm{Zn}$ concentrations in the leaves and stems [13,14]; grain Cd concentrations are easily affected [12]. This observation is strongly related to the regulated and small changes in phloem concentrations of $\mathrm{Zn}$, which may be in the form of Zn-NA complexes. In contrast, Cd loaded into phloem fluids may quickly bind to specific $\mathrm{Cd}$-binding proteins, and those are unsaturated with $\mathrm{Cd}$ and sufficiently present relative to $\mathrm{Cd}$, as described by Kato et al. [44]. Therefore, there are fewer limitations in the phloem transport of $\mathrm{Cd}$ than in $\mathrm{Zn}$ phloem transport.

The Fe in phloem sap may be derived largely from remobilization at the leaves (Figure 7, [55]) and probably bind to DMA and some citrate and proteins [43]. Therefore, the amount of Fe transport to the grains may be regulated by ligands and chelators. Schuler et al. [70] reported that in Arabidopsis thaliana, Fe-citrate in xylem sap may be delivered to the mature leaves and then Fe may be carried to the reproductive organs via the phloem as Fe-NA from the mature leaves. In the case of rice plants, Fe in the xylem is largely bound to citrate with slight binding to DMA [36]. Therefore, a large fraction of xylem Fe may be delivered first to the leaves as Fe-citrate and then to the seeds via the phloem, probably as Fe-DMA. It is possible that small amounts of Fe-DMA in rice xylem sap [36] travel through the xylem-to-phloem transport system at nodes by the OsYSL16 transporter [29]. Foliar application of a solution containing NA in addition to Fe and amino acids to a field-grown rice plant was found to increase the $\mathrm{Fe}$ and $\mathrm{Zn}$ concentrations in brown rice over those under a treatment with a solution containing Fe and amino acids [71].

\section{Molecular Technologies to Increase Grain Fe and $\mathrm{Zn}$ and to Reduce Grain Cd}

Recent attempts at the biofortification of $\mathrm{Fe}$ and $\mathrm{Zn}$ in rice grains using transgenic techniques have produced interesting results. The introduction of a yeast ferric chelate reductase gene to rice plants induced the enhancement of Fe uptake and an increase in grain yields but had no effect on $\mathrm{Fe}$ and $\mathrm{Zn}$ concentrations in the grains [72]. In contrast, the over-expression of the barley NA synthase gene $H v N A S 1$ in rice plants caused an increase in DMA and NA concentrations in roots, shoots, and seeds as well as of $\mathrm{Fe}, \mathrm{Zn}$, and $\mathrm{Cu}$ concentrations in grains [73]. These results are consistent with the proposed principle that the phloem-sap and grain concentrations of metals may be regulated by making use of the nature of metal-chelating compounds. It is valuable to note that high-NA grain may increase iron-bioavailability to mammals and humans [74,75].

There are three possible ways to reduce Cd content in rice grains: (1) the selection of lines/varieties with low $\mathrm{Cd}$ in phloem sap [44]; (2) more sequestration of $\mathrm{Cd}$ in the root-cell vacuoles by overexpression of OsHMA3 [25]; and (3) elimination of a Cd-uptake transporter (OsNRAMP5) in the root membranes [19]. Ishikawa et al. [19] report that carbon ion beam irradiation produced Cd-deficient rice mutants (Koshihikari-Kan1) with $<0.05 \mathrm{mg} \mathrm{Cd} \cdot \mathrm{kg}^{-1}$ in the grains compared with a mean of $1.1 \mathrm{mg} \mathrm{Cd} \cdot \mathrm{kg}^{-1}$ in the parent, cultivar Koshihikari (a high eating-quality rice) when plants were grown in 
Cd-contaminated fields, whereas their $\mathrm{Zn}$ and Fe concentrations were less affected (Table 4), and they also developed DNA markers to select cultivars carrying osnramp5. In terms of human intake of Cd from Cd-contaminated foods such as rice, its bioavailability and retention in the liver and kidneys are dramatically increased due to the deficiency of $\mathrm{Zn}, \mathrm{Fe}$, and $\mathrm{Ca}$ in foods [76]. Therefore, biofortification of $\mathrm{Zn}, \mathrm{Fe}$ and $\mathrm{Ca}$ in the grains is highly essential to reduce human $\mathrm{Cd}$ intake.

Table 4. Concentrations of $\mathrm{Zn}, \mathrm{Cd}$ and Fe of grains of cultivar Koshihikari (Koshi) and its OsNRAMP5-depleted mutant Koshihikari-Kan1 (Kan1) grown on three Cd-contaminated soils whose irrigation was treated with prolonged drainage after the early-period flooding. Data are means of 5 samples. ND, not detected. Data are from Ishikawa et al. [19].

\begin{tabular}{|c|c|c|c|c|c|c|}
\hline \multirow[t]{2}{*}{ Field (Soil Cd mg $\cdot \mathrm{kg}^{-1}$ ) } & \multicolumn{2}{|c|}{ Grain $\mathbf{Z n}\left(\mathbf{m g} \cdot \mathbf{k g}^{-1}\right)$} & \multicolumn{2}{|c|}{ Grain Cd $\left(\mathrm{mg} \cdot \mathrm{kg}^{-1}\right)$} & \multicolumn{2}{|c|}{ Grain Fe $\left(\mathrm{mg} \cdot \mathrm{kg}^{-1}\right)$} \\
\hline & Koshi & Kan1 & Koshi & Kan1 & Koshi & Kan1 \\
\hline $\mathrm{A}(1.35)$ & 48.8 & 36.9 & 0.57 & ND & 21.5 & 16.4 \\
\hline $\mathrm{B}(1.21)$ & 34.4 & 31.4 & 1.86 & 0.02 & 14.2 & 15.8 \\
\hline $\mathrm{C}(0.35)$ & 50.4 & 37.5 & 0.97 & 0.03 & 15.1 & 14.3 \\
\hline
\end{tabular}

\section{Conclusions}

$\mathrm{Zn}$ and $\mathrm{Fe}$ are essential nutrients for both plants and humans but $\mathrm{Cd}$ is non-essential and toxic if it accumulates at high levels for plants and, more severely, for humans. All three metals are contained in the grains of rice, a staple cereal worldwide. Several studies have reported that $\mathrm{Zn}$ and Fe concentrations in rice grains harvested under different levels of soil or hydroponic metals are known to change only within a small range, while grain $\mathrm{Cd}$ concentrations show greater changes and easily reach the allowable maximum in polished rice $\left(0.4 \mathrm{mg} \cdot \mathrm{kg}^{-1}\right)$ [77]. To gain insight into the mechanisms underlying such different metal contents, we synthesized information about the routes of metal transport and accumulation in rice plants, finding novel regulations involving metal speciation in xylem and phloem saps, metal transporters, and the xylem-to-phloem transport system. Specific metal transporters are involved in uptake in the roots, delivery to the shoots via the xylem-to-phloem transport system, and final transport to the grains via the phloem. Xylem sap $\mathrm{Zn}$ is in free ions and partially bound to unidentified chelators and has a highly variable concentration, while phloem sap $\mathrm{Zn}$ is dominantly $\mathrm{Zn}-\mathrm{NA}$ complex with a highly regulated concentration. Xylem sap $\mathrm{Cd}$ is primarily in free ions with a variable concentration, while phloem sap $\mathrm{Cd}$ is bound to proteins and thiol compounds, and its concentration is dependent on xylem sap $\mathrm{Cd}$. Cd loaded into phloem fluids may quickly bind to specific Cd-binding proteins, those are unsaturated with $\mathrm{Cd}$ and sufficiently present relative to $\mathrm{Cd}$. Xylem sap Fe (largely as Fe-citrate) is allocated to all leaves, while phloem Fe is bound to DMA, citrate, and proteins. At grain-filling, $\mathrm{Zn}$ and $\mathrm{Cd}$ ascending in xylem sap are transferred to the phloem by the xylem-to-phloem transport system operating at stem and panicle nodes, where xylem transfer cells and specific metal transporters are recognized. Grain Fe is largely derived from the leaves by remobilization. Thus, the concentrations of grain $\mathrm{Zn}$ and $\mathrm{Fe}$ are highly regulated within a small range, while that of grain $\mathrm{Cd}$ varies depending on xylem supply. Transgenic techniques to increase tissue and phloem-sap concentrations of NA and DMA are useful to increase grain $\mathrm{Zn}$ and Fe concentrations. The elimination of OsNRAMP5 Cd-uptake transporter and the enhancement of root cell vacuolar $\mathrm{Cd}$ sequestration reduce uptake and root-to-shoot transport, respectively, resulting in a great reduction of $\mathrm{Cd}$ accumulation in grains. 


\section{Acknowledgments}

The authors thank Reiko Nishiyama for her kind supply of information of $\mathrm{Zn}$ and Fe concentrations in rice xylem and phloem saps from her Master's thesis [39] and Mariyo Kato for providing her unpublished data of $\mathrm{Cd}$ concentrations in xylem and phloem saps as shown in Figure 3.

\section{Author Contributions}

Tadakatsu Yoneyama wrote the first draft of the manuscript and organized the tables and figures; Satoru Ishikawa and Shu Fujimaki reviewed the manuscript and added Table 4 and Figure 8, respectively.

\section{Conflicts of Interest}

The authors declare no conflicts of interest.

\section{References}

1. Nouet, C.; Motte, P.; Hanikenne, M. Chloroplastic and mitochondrial metal homeostasis. Trends Plant Sci. 2011, 16, 395-404.

2. Palmer, C.M.; Guerinot, M.L. Facing the challenges of $\mathrm{Cu}, \mathrm{Fe}$ and $\mathrm{Zn}$ homeostasis in plants. Nat. Chem. Biol. 2009, 5, 333-340.

3. Palmgren, M.G.; Clemens, S.; Williams, L.E.; Krämer, U.; Borg, S.; Schjørring, J.K.; Sanders, D. Zinc biofortification of cereals: Problems and solutions. Trends Plant Sci. 2008, 13, 464-473.

4. White, P.J.; Broadley, M.R. Physiological limits to zinc biofortification of edible crops. Front. Plant Sci. 2011, 2, 80.

5. Clemens, S.; Aarts, M.G.M.; Thomine, S.; Verbruggen, N. Plant science: The key to preventing slow cadmium poisoning. Trends Plant Sci. 2012, 18, 92-99.

6. Zimmermann, M.B.; Hurrell, R.F. Improving iron, zinc, vitamin A nutrition through plant biotechnology. Curr. Opin. Biotechnol. 2002, 13, 142-145.

7. Dijkhuizen, M.A.; Wieringa, F.T.; West, C.E. Zinc plus $\beta$-carotene supplementation of pregnant women is superior to $\beta$-carotene supplementation alone in improving vitamin A status in both mothers and infants. Am. J. Clin. Nutr. 2004, 80, 1299-1307.

8. Fukushima, M.; Ishizaki, A.; Sakamoto, M.; Kobayashi, E. Cadmium concentration in rice eaten by famers in the Jinzu River Basin. Jpn. J. Hyg. 1973, 28, 406-415. (In Japanese)

9. Khoshgoftarmanesh, A.H.; Schulin, R.; Chaney, R.L.; Daneshbakhsh, B.; Afyuni, M. Micronutrient-efficient genotypes for crop yield and nutritional quality in sustainable agriculture. A review. Agron. Sustain. Dev. 2010, 30, 83-107.

10. Simmons, R.W.; Pongsakul, P.; Chaney, R.L.; Saiyasitpanich, D.; Klinphoklap, S.; Nobuntou, W. The relative exclusion of zinc and iron from rice grain in relation to rice grain cadmium as compared to soybean: Implications for human health. Plant Soil 2003, 257, 163-170.

11. Wissuwa, M.; Ismail, A.M.; Graham, R.D. Rice grain zinc concentrations as affected by genotype, native soil-zinc availability, and zinc fertilization. Plant Soil 2008, 306, 37-48.

12. Ito, H.; Iimura, K. Absorption of zinc and cadmium by rice plants and their influence on its growth. II. Effect of cadmium. Jpn. J. Soil Sci. Plant Nutr. 1976, 47, 44-48. 
13. Ito, H.; Iimura, K. Absorption of zinc and cadmium by rice plants and their influence on its growth. I. Effect of zinc. Jpn. J. Soil Sci. Plant Nutr. 1976, 47, 39-43.

14. Jiang, W.; Struik, P.C.; van Keulen, H.; Zhao, M.; Jin, L.N.; Stomph, T.J. Does increased zinc uptake enhance grain zinc mass concentration in rice? Ann. Appl. Biol. 2008, 153, 135-147.

15. Shiratori, K.; Suzuki, T.; Miyoshi, H. Chemical forms of soil zinc in the salt-rich reclaimed fields, where zinc-deficiency symptoms were observed in rice plants. Jpn. J. Soil Sci. Plant Nutr. 1972, 43, 291-296.

16. Khaokaew S.; Chaney, R.L.; Landrot, G.; Ginder-Vogel, M.; Sparks, D.L. Speciation and release kinetics of cadmium in an alkaline paddy soil under various flooding periods and draining conditions. Environ. Sci. Technol. 2011, 45, 4249-4255.

17. Hashimoto, Y.; Yamaguchi, N. Chemical speciation of cadmium and sulfur K-edge XANES spectroscopy in flooded paddy soils amended with zerovalent iron. Soil Sci. Soc. Am. J. 2013, 77, 1189-1198.

18. Lee, S.; An, G. Over-expression of OsIRT1 leads to iron and zinc accumulations in rice. Plant Cell Environ. 2009, 32, 408-416.

19. Ishikawa, S.; Ishimaru, Y.; Igura, M.; Kuramata, M.; Abe, T.; Senoura, T.; Hase, Y.; Arao, T.; Nishizawa, N.K.; Nakanishi, H. Ion-beam irradiation, gene identification, and marker-assisted breeding in the development of low-cadmium rice. Proc. Natl. Acad. Sci. USA 2012, 109, 19166-19171.

20. Sasaki, A.; Yamaji, N.; Yokosho, K.; Ma, J.F. Nramp5 is a major transporter responsible for manganese and cadmium uptake in rice. Plant Cell 2012, 24, 2155-2167.

21. Nakanishi, H.; Ogawa, I.; Ishimaru, Y.; Mori, S.; Nishizawa, N.K. Iron deficiency enhances cadmium uptake and translocation mediated by the $\mathrm{Fe}^{2+}$ transporters OsIRT1 and OsIRT2 in rice. Soil Sci. Plant Nutr. 2006, 52, 464-469.

22. Inoue, H.; Kobayashi, T.; Nozoye, T.; Takahashi, M.; Kakei, Y.; Suzuki, K.; Nakazono, M.; Nakanishi, H.; Mori, S.; Nishizawa, N.K. Rice OsYSL15 is an iron-regulated iron(III)-deoxymugineic acid transporter expressed in the roots and is essential for iron uptake in early growth of the seedlings. J. Biol. Chem. 2009, 284, 3470-3479.

23. Ishimaru, Y.; Suzuki, M.; Tsukamoto, T.; Suzuki, K.; Nakazono, M.; Kobayashi, T.; Wada, Y.; Watanabe, S.; Matsuhashi, S.; Takahashi, M.; et al. Rice plants take up iron as an $\mathrm{Fe}^{3+}$-phytosiderophore and as $\mathrm{Fe}^{2+}$. Plant J. 2006, 45, 335-346.

24. Haydon, M.J.; Kawachi, M.; Wirtz, M.; Hillmer, S.; Hell, R.; Krämer, U. Vacuolar nicotianamine has critical and distinct roles under iron deficiency and for zinc sequestration in Arabidopsis. Plant Cell 2012, 24, 724-737.

25. Ueno, D.; Yamaji, N.; Kono, I.; Huang, C.F.; Ando, T.; Yano, M.; Ma, J.F. Gene limiting cadmium accumulation in rice. Proc. Natl. Acad. Sci. USA 2010, 107, 16500-16505.

26. Nocito, F.F.; Lancilli, C.; Dendena, B.; Lucchini, G.; Sacchi, G.A. Cadmium retention in rice roots is influenced by cadmium availability, chelation and translocation. Plant Cell Environ. 2011, 34, 994-1008.

27. Takahashi, R.; Ishimaru, Y.; Shimo, H.; Ogo, Y.; Senoura, T.; Nishizawa, N.K.; Nakanishi, H. The OsHMA2 transporter is involved in root-to-shoot translocation of $\mathrm{Zn}$ and $\mathrm{Cd}$ in rice. Plant Cell Environ. 2012, 35, 1948-1957. 
28. Yamaji, N.; Xia, J.; Mitani-Ueno, N.; Yokosho, K.; Ma, J.F. Preferential delivery of zinc to developing tissues in rice is mediated by P-type heavy metal ATPase OsHMA2. Plant Physiol. 2013, 162, 927-939.

29. Kakei, Y.; Ishimaru, Y.; Kobayashi, T.; Yamakawa, T.; Nakanshi, H.; Nishizawa, N.K. OsYSL16 plays a role in the allocation of iron. Plant Mol. Biol. 2012, 79, 583-594.

30. Lee, S.; Chiecko, J.C.; Kim, S.A.; Walker, E.L.; Lee, Y.; Guerinot, M.L.; An, G. Disruption of OsYSL15 leads to inefficiency in rice plants. Plant Physiol. 2009, 150, 786-800.

31. Aoyama, T.; Kobayashi, T.; Takahashi, M.; Nagasaka, S.; Usuda, K.; Kakei, Y.; Ishimaru, Y.; Nakanishi, H.; Mori, S.; Nishizawa, N.K. OsYSL18 is a rice iron(III)-deoxymugineic acid transporter specifically expressed in reproductive organs and phloem of lamina joints. Plant Mol. Biol. 2009, 70, 681-692.

32. Widodo; Broadley, M.R.; Rose, T.; Frei, M.; Pariasca-Tanaka, J.; Yoshihashi, T.; Thomson, M.; Hammond, J.P.; Aprile, A.; Close, T.J.; et al. Response to zinc deficiency of two rice lines with contrasting tolerance is determined by root growth maintenance and organic acid exudation rate, and not by zinc-transport activity. New Phytol. 2010, 186, 400-414.

33. Takagi, S.; Nomoto, K.; Takemoto, S. Physiological aspect of mugineic acid, a possible phytosiderophore of graminaceous plants. J. Plant Nutr. 1984, 7, 469-477.

34. Nozoye, T.; Nagasaka, S.; Kobayashi, T.; Takahashi, M.; Sato, Y.; Uozumi, N.; Nakanishi, H.; Nishizawa, N.K. Phytosiderophore efflux transporters are crucial for iron acquisition in graminaceous plants. J. Biol. Chem. 2011, 286, 5446-5454.

35. Weber, G.; von Wiren, N.; Hayen, H. Investigation of ascorbate-mediated iron release from ferric phytosiderophores in the presence of nicotianamine. Biometals 2008, 21, 503-513.

36. Ariga, T.; Hazama, K.; Yanagisawa, S.; Yoneyama, T. Chemical forms of iron in xylem sap from graminaceous and non-graminaceous plants. Soil Sci. Plant Nutr. 2014, 60, 460-469.

37. Park, J.; Song, W.-Y.; Ko, D.; Eom, Y.; Hansen, T.H.; Schiller, M.; Lee, T.G.; Martinoia, E.; Lee, Y. The phytochelatin transporters AtABCC1 and AtABCC2 mediate tolerance to cadmium and mercury. Plant J. 2012, 69, 278-288.

38. Ishikawa, S.; Suzui, N.; Ito-Tanabata, S.; Ishii, S.; Igura, M.; Abe, T.; Kuramata, M,; Kawachi, N.; Fujimaki, S. Real-time imaging and analysis of differences in cadmium dynamics in rice cultivars (Oryza sativa) using positron-emitting ${ }^{107} \mathrm{Cd}$ trace. BMC Plant Biol. 2011, 11, 172.

39. Yokosho, K.; Yamaji, N.; Ueno, D.; Mitani, N.; Ma, J.F. OsFRDL1 is a citrate transporter required for efficient transformation of iron in rice. Plant Physiol. 2009, 149, 297-305.

40. Kawabe, S.; Fukumorita, T.; Chino, M. Collection of rice phloem sap from stylets of homopterous insects severed by YAG laser. Plant Cell Physiol. 1980, 21, 1319-1327.

41. Nishiyama, R. Zinc Transport via Phloem in Rice Plants. Master thesis, Graduate School of Agricultural and Life Sciences, the University of Tokyo, Tokyo, Japan, 2006.

42. Kato, M. The University of Tokyo, Tokyo, Unpublished work, 2006.

43. Nishiyama, R.; Kato, M.; Nagata, S.; Yanagisawa, S.; Yoneyama, T. Identification of Zn-nicotianamine and Fe-2'-deoxymugineic acid in the phloem sap from rice plants (Oryza sativa L.). Plant Cell Physiol. 2012, 53, 381-390. 
44. Kato, M.; Ishikawa, S.; Inagaki, K.; Chiba, K.; Hayashi, H.; Yanagisawa, S.; Yoneyama, T. 2010: Possible chemical forms of cadmium and varietal differences in cadmium concentrations in the phloem sap of rice plants (Oryza sativa L.). Soil Sci. Plant Nutr. 2010, 56, 839-847.

45. Álvarez-Fernández, A.; Díaz-Benito, P.; Abadía, A.; Lopez-Millán, A.-F.; Abadía, J. 2014: Metal species involved in long distance metal transport in plants. Front. Plant Sci. 2014, 5, 105.

46. Ando, Y.; Nagata, S.; Yanagisawa, S.; Yoneyama, T. Copper in xylem and phloem from rice (Oryza sativa): The effect of moderate copper concentrations in the growth medium on the accumulation of five essential metals and a speciation analysis of copper-containing compounds. Funct. Plant Biol. 2013, 40, 89-100.

47. Obata, H.; Kitagishi, K. Longitudinal distribution pattern of zinc and manganese in leaf with special reference to aging. Jpn. J. Soil Sci. Plant Nutr. 1980, 51, 285-291.

48. Kitagishi, K.; Obata, H.; Kondo, T. Effect of zinc deficiency on $80 \mathrm{~S}$ ribosome content of meristematic tissues of rice plant. Soil Sci. Plant Nutr. 1987, 33, 423-429.

49. Obata, H.; Kitagishi, K. Accumulation and retranslocation of zinc in a leaf of rice plant with reference to aging. Jpn. J. Soil Sci. Plant Nutr. 1982, 53, 235-240.

50. Kitagishi, K.; Obata, H. Retrieval of zinc from transpiration stream in the nodes of rice plants as affected by the concentration of zinc in culture solution. Rep. Environ. Sci. Mie Univ. 1982, 7, 91-97.

51. Yamaguchi, N.; Ishikawa, S.; Abe, T.; Baba, K.; Arao, T.; Terada, Y. Role of the node in controlling traffic of cadmium, zinc, and manganese in rice. J. Exp. Bot. 2012, 63, 2729-2737.

52. Kitagishi, K.; Obata, H. Distribution of ${ }^{115 \mathrm{~m}} \mathrm{Cd}$ in rice plants absorbed by roots at vegetative stage. Rep. Environ. Sci. Mie Univ. 1979, 4, 59-65.

53. Kobayashi, N.I.: Tanoi, K.; Hirose, A.; Nakanishi, T.M. Characterization of rapid intervascular transport of cadmium in rice stem by radioisotope imaging. J. Exp. Bot. 2013, 64, 507-517.

54. Tsukamoto, T.; Nakanishi, H.; Uchida, H.; Watanabe, S.; Matsuhashi, S.; Mori, S.; Nishizawa, N.K. 2009: ${ }^{52} \mathrm{Fe}$ translocation in barley as monitored by a positron emitting tracer imaging system (PETIS): Evidence for the direct translocation of Fe from roots to young leaves via phloem. Plant Cell Physiol. 2009, 50, 48-57.

55. Yoneyama, T.; Gosho, T.; Kato, M.; Goto, S.; Hayashi, H. Xylem and phloem transport of Cd, $\mathrm{Zn}$ and $\mathrm{Fe}$ into the grains of rice plants (Oryza sativa L.) grown in continuously flooded Cd-contaminated soil. Soil Sci. Plant Nutr. 2010, 56, 445-453.

56. Zee, S.-Y. Transfer cells and vascular tissue distribution in the vegetative nodes of rice. Aust. J. Bot. 1972, 20, 41-48.

57. Kawahara, H.; Chonan, N.; Matsuda, T. Studies on morphogenesis in rice plants. 7. The morphology of vascular bundles in the vegetative nodes of the culm. Proc. Crop Sci. Soc. Jpn. 1974, 43, 389-401.

58. Chonan, N.; Kawahara, H.; Matsuda, T. Ultrastructure of elliptical and diffuse bundles in the vegetative nodes of rice. Jpn. J. Crop Sci. 1984, 54, 393-402.

59. Wu, C.-Y.; Lu, L.-L.; Yang, X.-E.; Feng, Y.; Wei, Y.-Y.; Hao, H.-L.; Stoffella, P.J.; He, Z.-L. Uptake, translocation, and remobilization of zinc absorbed at different growth stages by rice genotypes of different Zn densities. J. Agric. Food Chem. 2010, 58, 6767-6773. 
60. Nishiyama, R.; Tanoi, K.; Yanagisawa, S.; Yoneyama, T. 2013: Quantification of zinc transport to the grain in rice plants (Oryza sativa L.) at early grain-filling by a combination of mathematical modeling and ${ }^{65} \mathrm{Zn}$ tracing. Soil Sci. Plant Nutr. 2013, 59, 750-755.

61. Tanaka, K.; Fujimaki, S.; Fujiwara, T.; Yoneyama, T.; Hayashi, H. Quantitative estimation of the contribution of the phloem in cadmium transport to grains in rice plants (Oryza sativa L.). Soil Sci. Plant Nutr. 2007, 53, 72-77.

62. Rodda, M.S.; Li, G.; Reid, R.J. The timing of grain Cd accumulation in rice plants: The relative importance of remobilization within the plant and root Cd uptake post-flowering. Plant Soil 2011, 347, 105-114.

63. Fujimaki, S.; Suzui, N.; Ishioka, N.S.; Kawachi, N.; Ito, S.; Chino, M.; Nakamura, S. Tracing cadmium from culture to spikelet: Noninvasive imaging and quantitative characterization of absorption, transport, and accumulation of cadmium in an intact rice plant. Plant Physiol. 2010, 152, 1796-1806.

64. Zee, S.-Y. Vascular tissue and transfer cell distribution in the rice spikelet. Aust. J. Biol. Sci. 1972, 25, 411-414.

65. Kawahara, H.; Matsuda, T.; Chonan, N. Studies on morphogenesis in rice plants. 9. On the structure of vascular bundles and phloem transport in the spikelet. Proc. Crop Sci. Soc. Jpn. 1977, $46,82-90$.

66. Herren, T.; Feller, U. Transfer of zinc from xylem to phloem in the peduncle of wheat. J. Plant Nutr. 1994, 17, 1587-1598.

67. Jiang, W.; Struik, P.C.; Lingna, J.; van Keulen, H.; Ming, Z.; Stomph, T.J. Uptake and distribution of root-applied or foliar-applied ${ }^{65} \mathrm{Zn}$ after flowering in aerobic rice. Ann. Appl. Biol. 2007, 150, 383-391.

68. Sperotto, P.A.; Ricachenevsky, F.K.; Waldow, V.A.; Fett, J.P. Iron biofortification in rice: It's a long way to the top. Plant Sci. 2012, 190, 24-39.

69. Moritsugu, M. A study on combination of glutelin with cadmium in rice grain. Ber. Obara Inst. Landwirtsch. Biol. 1964, 12, 251-260.

70. Schuler, M.; Rellán-Álvarez, R.; Fink-Straube, C.; Abadía, J.; Bauer, P. Nicotianamine functions in the phloem-based transport of iron to sink organs in pollen development and pollen tube growth in Arabidopsis. Plant Cell 2012, 24, 2380-2400.

71. Yuan, L.; Wu, L.; Yang, C.; Lv, Q. Effects of iron and zinc foliar applications on rice plants and their grain accumulation and grain quality. J. Sci. Food Agric. 2012, 93, 254-261.

72. Ishimaru, Y.; Kim, S.; Tsukamoto, T.; Oki, H.; Kobayashi, T.; Watanabe, S.; Matsuhashi, S.; Takahashi, M.; Nakanishi, H.; Mori, S.; et al. Mutational reconstructed ferric chelate reductase confers enhanced tolerance in rice to iron deficiency in calcareous soil. Proc. Natl. Acad. Sci. USA 2007, 104, 7373-7378.

73. Masuda, H.; Usuda, K.; Kobayashi, T.; Ishimaru, Y.; Kakei, Y.; Takahashi, M.; Higuchi, K.; Nakanishi, H.; Mori, S.; Nishizawa, K.N. Overexpression of the barley nicotianamine synthase gene HvHAS1 increases iron and zinc concentrations in rice grains. Rice 2009, 2, 155-166.

74. Lee, S.; Jeon, U.S.; Lee, S.J.; Kim, Y.-K.; Persson, D.P.; Husted, S.; Schjørring, J.K.; Kakei, Y.; Masuda, H.; Nishizawa, N.K.; et al. Iron fortification of rice seeds through activation of the nicotianamine synthase gene. Proc. Nat. Acad. Sci. USA 2009, 106, 22014-22019. 
75. Zheng, L.; Cheng, Z.; Ai, C.; Jiang, X.; Bei, X.; Zheng, Y.; Glahn, R.P.; Welch, R.M.; Miller, D.D.; Lei, X.G.; et al. Nicotianamine, a novel enhancer of rice iron bioavailability to humans. PLoS ONE 2010, 5, e10190.

76. Reeves, P.G.; Chaney, R.L. Bioavailability as an issue in risk assessment and management of food cadmium: A review. Sci. Total Environ. 2008, 398, 13-19.

77. Codex Alimentarius (2014) CODEX STAN 193-1995, General Standard for Contaminants and Toxins in Food and Feed. Available online: http://www.codexalimentarius.org/download/standards/ 17/CXS_193e2015.pdf (accessed on 31 March 2015).

(C) 2015 by the authors; licensee MDPI, Basel, Switzerland. This article is an open access article distributed under the terms and conditions of the Creative Commons Attribution license (http://creativecommons.org/licenses/by/4.0/). 